Int. J. Morphol.,

31(1):107-109, 2013

\title{
A Case of Unilateral Fenestration and Duplication of the External Jugular Vein
}

\author{
Un Caso de Fenestración Unilateral y Duplicación de la Vena Yugular Externa
}

\author{
"Ziga Snoj" \& Erika Cvetko**
}

SNOJ, Z. \& CVETKO, E. A case of unilateral fenestration and duplication of the external jugular vein. Int. J. Morphol., 31(1):107$109,2013$.

SUMMARY: The external jugular vein is increasingly being utilized as the recipient vein in head and neck free tissue transfers, and for cannulation in order to conduct diagnostic procedures or intravenous therapies. The variations in the patterns of its course, and knowledge of them, are therefore important. We report on a unique and previously non-described unilateral fenestration and duplication of the external jugular vein found during the neck dissection of a 77-year-old female cadaver. Embryological evaluation and clinical implications of the anomaly are described. Clinicians and surgeons performing neck vascular or reconstructive surgery should be aware of this variation of the external jugular vein in the hope of preventing inadvertent injury.

KEY WORDS: External jugular vein; Anatomical variation, Fenestration; Duplication.

\section{INTRODUCTION}

The superficial veins, especially the external jugular vein (EJV), are increasingly being utilized for cannulation to conduct diagnostic procedures or intravenous therapies. Information obtained from the EJV examination at critically ill patients can be used to assess central venous pressure, which may provide useful data about intravascular volume status, presence of congestive heart failure, or other abnormal conditions (Vinayak et al., 2006). The EJV is also used in microsurgical procedures as a recipient vein for the free flaps (Cheng et al., 2012). The variations in the patterns of its course, and knowledge of them, are therefore important. Various authors have described phlebectasia (Hermans, 1991), saccular aneurysm (Verbeeck et al., 1997), fenestration (Cvetko, 2012), duplication of the EJV (Comert \& Comert, 2009), anastomosis between the EJV and internal jugular vein (IJV) (Chalian et al., 2001; Lalwani et al., 2006), and draining of left EJV into right subclavian vein (Rajanigandha et al., 2008). We report on unilateral fenestration and duplication of the EJV, an entity that has not yet been reported.

\section{CASE REPORT}

During a course of applied clinical anatomy for dental students and dissection of the neck of a 77-years-old female cadaver, a large fenestration and short duplication of the EJV was observed on the left side after removing the skin with the platysma muscle (Fig 1). Retromandibular vein (RMV) was formed in the substance of parotid gland by the union of maxillary vein and superficial temporal vein as usual. The EJV formed by the union of the posterior division of the RMV and the posterior auricular vein at the level of the angle of the mandible. The EJV bifurcated $1.5 \mathrm{~cm}$ below its

\footnotetext{
"Student, Medical Faculty, University of Ljubljana, Ljubljana, Slovenia.

${ }^{* *}$ Professor of Anatomy, Institute of Anatomy, Medical Faculty, University of Ljubljana, Ljubljana, Slovenia.
}

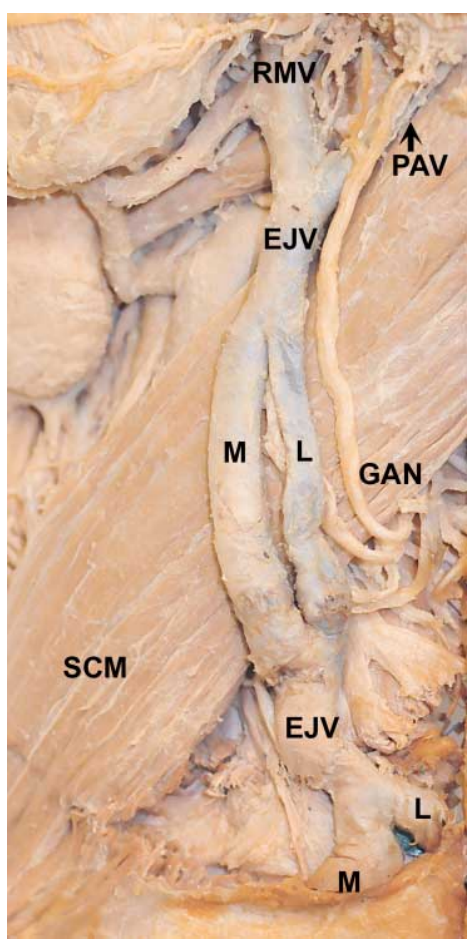

Fig. 1. Dissection showing the left side of the neck with the fenestration and duplication of the external jugular vein (EJV): $\mathrm{M}$ - medial branch; L - lateral branch; RMV - retromandibular vein; PAV - posterior auricular vein; SCM sternocleidomastoid muscle; GAN - great auricular nerve. 
origin into a larger, medial branch $(6-7 \mathrm{~mm}$ in diameter) and a smaller, lateral branch (3-4 $\mathrm{mm}$ in diameter), which reunited after a length of $3.5 \mathrm{~cm}$. After a short single stem of $2 \mathrm{~cm}$ in length the EJV bifurcated again into medial and lateral EJV of $2 \mathrm{~cm}$ in length that emptied separately into the subclavian vein (not shown, since the subclavian vein remained in the thorax after the removal of the head and neck). The great auricular nerve (GAN) ascended posteriorly parallel to the EJV. No structure passed through fenestrated part of the EJV. No variation of the IJV was observed. The veins on the right side of the neck showed no significant variations.

\section{DISCUSSION}

In many of the craniocervical arteries, divisions (fenestrations or duplications) have been described, but venous divisions only rarely so (Towbin \& Kanal, 2004). Divisions (fenestrations or duplications) of the IJV are estimated to occur in as much as $0.4 \%$ of the population (Prades et al., 2002). In order to avoid confusion between the terms duplication and fenestration, which are used interchangeably in the literature available, Downie et al., (2007) suggested that the term duplication be limited to those cases in which the branches of the anomalous vessel remain separate over the entire course, whereas the term fenestration should be used for those cases in which the branched vessel reunites into a single normal vessel.

We were able to find only two publications on EJV division in the literature available (Comert \& Comert; Cvetko, 2012). Comert \& Comert have reported on unilateral EJV duplication observed during neck surgery. Since the duplicated segment was described in the middle part of the EJV, which reunited again into a single stem, the anomaly concerned was in fact fenestration and not duplication. Cvetko reported on unilateral EJV fenestration, through which the cervical branch of the facial nerve passed. The venous anomaly presented in our case is unique, since both fenestration (superior duplicated segment) and duplication (inferior duplicated segment which emptied into subclavian vein separately) were observed on the left EJV (Downie et al.).
It has been postulated that vessel duplication may be due to derangement from early development between the third and sixth gestational weeks (Rossi \& Tortori-Donati, 2001). IJV duplication is usually reported in association with phlebectasia, suggesting the abnormal development of the venous wall, possibly involving incomplete formation of the muscular layer (Som et al., 1985; Rossi \& Tortori-Donati; Turan-Ozdemir et al., 2004).

The ease of the EJV access has facilitated its use for therapeutic procedures and for monitoring by clinicians. It is often considered as a safe and suitable alternative when the cephalic vein approach is not feasible, e.g. for totally implantable venous access device placement (Di Carlo et al., 2005) or for insertion of temporary hemodialysis catheter (Moini et al., 2009). In peadiatric patients the EJV is a viable site for central venous access with a lower complication rate than the IJV approach (Tecklenburg et al., 2010). The EJV is usually grafted into the carotid during endarterectomy (Sabharwal \& Mukherjee, 1998), and also used for surgery involving microvascular anastomosis in reconstruction procedures (Cheng et al.).

The EJV has also been used to monitor central venous pressure (Parker et al., 2002). Estimation of the EJV pressure at fenestrated part of the EJV as presented in our study could underestimate the EJV pressure. The EJV with double and single segments raises the possibility of the potential for deep venous thrombus formation secondary to changes in flow velocities. It was calculated from short-segments of superficial femoral vein duplications a mean increase in the vessel's total cross sectional area of $42 \%$, which corresponded to a decrease in blood flow velocity of $36 \%$ (Dona et al., 2000).

Fenestration with duplication of the EJV is a rare anomaly. Clinicians and surgeons performing neck vascular or reconstructive surgery should be aware of this unexpected variation of the EJV in the hope of preventing inadvertent injury.

ACKNOWLEDGMENTS. The dissecting work of Ivan Blazinovic and the photographic work of Franci Medvescek are highly acknowledged.

SNOJ, Z. \& CVETKO, E. Un caso de fenestración unilateral y duplicación de la vena yugular externa. Int. J. Morphol., 31(1):107-109, 2013.

RESUMEN: La vena yugular externa se está utilizando cada vez como vena receptora en la transferencias de tejidos libres de cabeza y cuello, y para canulización en procedimientos de diagnóstico o terapias intravenosas. Las variaciones en los patrones de su curso, y el conocimiento de los mismos son relevantes. Se reporta una fenestración unilateral, no descrita previamente, y la duplicación de la vena yugular externa encontrada durante la disección del cadáver de una mujer de 77 años de edad. Se hace una evaluación embriológica y las implicaciones clínicas de esta anomalía. Los médicos y cirujanos que realizan cirugía vascular o reconstructiva de cuello deben tener en cuenta esta variación de la vena yugular externa con el fin de prevenir lesiones accidentales.

PALABRAS CLAVE: Vena yugular externa; Variación anatómica; Fenestraciones; Duplicación. 


\section{REFERENCES}

Chalian, A. A.; Anderson, T. D.; Weinstein, G. S. \& Weber, R. S. Internal jugular vein versus external jugular vein anastomosis: implications for successful free tissue transfer. Head Neck, 23(6):475-8, 2001.

Cheng, H. T.; Lin, F. Y. \& Chang, S. C. External or internal jugular vein? Recipient vein selection in head and neck free tissue transfer: an evidence-based systematic analysis. Plast. Reconstr. Surg., 129(4):730e-1e, 2012.

Comert, E. \& Comert, A. External jugular vein duplication. $J$. Craniofac. Surg., 20(6):2173-4, 2009.

Cvetko, E. A case of unilateral fenestration of the external jugular vein, through which the cervical branch of the facial nerve passes. Anat. Sci. Int., 2012. Epub ahead of print. DOI 10:1007/ s12565-012-0155-9.

Di Carlo, I.; Barbagallo, F.; Toro, A.; Sofia, M.; Lombardo, R. \& Cordio, S. External jugular vein cutdown approach, as a useful alternative, supports the choice of the cephalic vein for totally implantable access device placement. Ann. Surg. Oncol., 12(7):570-3, 2005.

Dona, E.; Fletcher J. P.; Hughes T. M.; Saker, K.; Batiste, P. \& Ramanathan, I. Duplicated popliteal and superficial femoral veins: incidence and potential significance. Aust. N. Z. J. Surg., 70(6):438-40, 2000.

Downie, S. A; Schalop, L.; Mazurek, J. N.; Savitch, G.; Lelonek, G.J. \& Olson, T.R. Bilateral duplicated internal jugular veins: case study and literature review. Clin. Anat., 20(3):260-6, 2007.

Hermans, R. Phlebectasia of the external jugular vein: a case report. J. Belge Radiol., 74(3):221-2, 1991.

Lalwani, R.; Rana, K. K.; Das, S. \& Khan, R. Q. Communication of the external and internal jugular veins: a case report. Int. J. Morphol., 24(4):721-2, 2006.

Moini, M.; Rasouli, M. R.; Kenari, M. M. \& Mahmoodi, H. R. Non-cuffed dual lumen catheters in the external jugular veins versus other central veins for hemodialysis patients. Saudi J. Kidney Dis. Transpl., 20(1):44-8, 2009.

Parker, J. L.; Flucker, C. J.; Harvey, N.; Maguire, A. M.; Russell, W. C. \& Thompson, J. P. Comparison of external jugular and central venous pressures in mechanically ventilated patient. Anaesthesia, 57(6):596-600, 2002.

Prades, J. M.; Timoshenko, A.; Dumollard, J. M.; Durand, M.; Merzougui, N. \& Martin, C. High duplication of internal jugular vein: clinical incidence in the adult and surgical consequences, a report of three clinical cases. Surg. Radiol. Anat., 24(2):129$32,2002$.
Rajanigandha, V.; Rajalakshmi, R.; Ranade, A. V.; Pai, M. M.; Prabhu, L. V.; Ashwin, K. \& Jiji, P. J. An anomalous left external jugular vein draining into right subclavian vein: a case report. Int. J. Morphol., 26(4):893-5, 2008.

Rossi, A. \& Tortori-Donati, P. Internal jugular vein phlebectasia and duplication. Pediatr. Radiol., 31(2):134, 2001.

Sabharwal, P. \& Mukherjee, D. Autogenous common facial vein or external jugular vein patch for carotid endarterectomy. Cardiovasc. Surg., 6(6):594-7, 1998.

Som, P. M.; Shugar, J. M.; Sacher, M. \& Lanzieri, C. F. Internal jugular vein phlebectasia and duplication: CT features. $J$. Comput. Assist. Tomogr., 9(2):390-2, 1985.

Tecklenburg, F.; Cochran, J. B.; Webb, S. A.; Habib, D. M. \& Losek, J. D. Central venous access via external jugular vein in children. Pediatr. Emerg. Care, 26(8):554-7, 2010.

Towbin, A. J. \& Kanal, E. A review of two cases of fenestrated internal jugular veins as seen by CT angiography. AJNR. Am. J. Neuroradiol., 25(8):1433-4, 2004.

Turan-Ozdemir, S.; Coskun, H. \& Balban, M. Phlebectasia of the external jugular vein associated with duplication of the internal jugular vein. Clin. Anat., 17(6):522-5, 2004.

Verbeeck, N.; Hammer, F.; Goffette, P. \& Mathurin, P. Saccular aneurysm of the external jugular vein, an unusual cause of neck swelling. J. Belge Radiol., 80(2):63-4, 1997.

Vinayak, A. G.; Levitt, J.; Gehlbach, B.; Pohlman, A. S.; Hall, J. B. \& Kress, J. P. Usefulness of the external jugular vein examination in detecting abnormal central venous pressure in critically ill patients. Arch. Intern. Med., 166(19):2132-7, 2006.

Correspondence to:

Erika Cvetko, DMD, PD

Professor of Anatomy

Institute of Anatomy

Medical Faculty

Korytkova 2, 1000 Ljubljana

SLOVENIA

Phone: +386-1-5437303

Fax: +386-1-5437301

Email: erika.cvetko@mf.uni-lj.si
Received: 04-09-2012

Accepted: 21-12-2012 